\title{
HLA antigens in chronic relapsing idiopathic inflammatory polyneuropathy
}

\author{
D I A A A D AMS, H. FESTENSTEIN, J. D. G I B S N, \\ R. A. C. HUG HES, J. JAR A Q U EMA D A, C. P A P A S T E R A D IS, \\ J. S A C H S, A N D P. K. THOM A S \\ From the Department of Neurological Science and Tissue Typing Laboratory, Royal Free Hospital, \\ Department of Immunology, London Hospital Medical College, and Neurology Department, \\ Guy's Hospital, London
}

SUMMARY Observations are reported on 14 patients with a clinical diagnosis of recurrent or chronic relapsing idiopathic inflammatory polyneuropathy of Guillain-Barré type. The results suggest the possibility of a disease susceptibility gene for this disorder associated with the HLA-A1, -B8, -DRw3, and -Dw3 haplotype.

Most cases of idiopathic inflammatory polyneuropathy exhibit an acute monophasic illness (Guillain-Barré syndrome). Recurrences are uncommon. Other clinically similar cases display a more gradual onset and show a chronic relapsing or chronic progressive course. As in the acute disease, they are characterised by predominantly motor involvement, severely reduced nerve conduction velocity, and raised cerebrospinal fluid protein levels. The histological features are similar in the acute and both the chronic relapsing (Thomas et al., 1969) and chronic progressive (Dyck et al., 1975) forms, with extensive segmental demyelination in peripheral nerve trunks and spinal roots associated with focal accumulations of mononuclear cells. It has, therefore, been suggested that these disorders are variants of the same condition (Thomas et al., 1969).

There are close parallels between experimental allergic neuritis (EAN) and the Guillain-Barré syndrome. Experimental allergic neuritis probably represents a cell-mediated, delayed hypersensitivity reaction to peripheral nerve antigens and provides a useful animal model for the Guillain-Barré syndrome (Arnason, 1975). The usual pattern in EAN is an acute monophasic illness, but a small proportion of animals pursue a chronic progressive or relapsing course (Pollard et al., 1975). It is thus possible that the latter parallel the chronic relapsing human cases.

Address for correspondence and reprint requests: Professor P. K. Thomas, Department of Neurological Science, Royal Free Hospital, Pond Street, London NW3 2QG.

Accepted 11 September 1978
The HLA associations that have been established for a number of autoimmune disorders prompted us to examine the situation in idiopathic demyelinating neuropathy. In 59 cases of the GuillainBarré syndrome of acute onset, we found no deviation in the frequency of HLA-A, -B or -C antigens (Adams et al., 1977). The lack of any such association has since been confirmed in two further reports (Latovitski et al., 1978; Stewart et al., 1978).

In this communication, we present preliminary results on the distribution of HLA-A, -B, -C, $-D R$, and -D locus antigens in a series of patients with recurrent or chronic relapsing idiopathic inflammatory polyneuropathy.

\section{Results}

The observations were made on 14 cases diagnosed as recurrent or chronic relapsing idiopathic inflammatory polyneuropathy on the basis of their clinical features, raised CSF protein level, nerve conduction studies, and, in some instances, sural or radial nerve biopsy. It was difficult to distinguish recurrent cases-that is, with recovery between episodes-from chronic relapsing cases without recovery between exacerbations. Both variants have, therefore, been included together. All cases had at least two relapses.

Eight HLA-DR antigens were defined by a panel of selected antisera used in the 1977 Histocompatibility Workshop (Bodmer et al., 1978). The HLA-D specificities were identified by the use of homozygous typing cells accredited in the 1975 
and 1977 Histocompatibility Workshops (Thorsby and Piazza, 1975; Festenstein et al., 1978). Each patient was tested at least twice for eight specificities (HLA-Dwl-Dw8), and at least two Dw3 cells were incorporated in each experiment.

The HLA-A, -B, -C, -DR, and -D phenotypes for each patient are given in Table 1. There was a significant increase $(P<0.02)$ in the frequency of HLA-B8 $(50 \%)$ as compared with $25 \%$ in a control panel of 571 individuals (Adams et al., 1977). The frequency of the HLA-D region antigens is given in Table 2. When compared with the frequencies in 351 European Caucasoids, there was a significant increase in HLA-DRw $3(50 \%$ versus $17 \%, \mathrm{P}<0.05)$. The frequency of HLA-Dw3 was also increased $(37 \%$ versus $21 \%, \quad P<0.05)$. Although it was not possible to establish the individual haplotypes without family segregation studies, it is interesting to note that of the five individuals who were HLA-A1, -B8, and -Dw3, three were also HLA-DRw3. However, both HLA -Dw3 and -DRw3 specificities are among those that are not yet clearly defined (Bodmer et al., 1978; Festenstein et al., 1978). HLA-B8, which has the strongest association, is a well-established specificity.

Table 1 Frequency of $H L A$ antigens in patients with chronic relapsing idiopath:c inflammatory polyneuropathy

\begin{tabular}{|c|c|c|c|c|c|}
\hline \multirow[t]{2}{*}{ Case } & \multicolumn{3}{|c|}{$H L A-$} & \multirow[t]{2}{*}{$H L A-D R w$} & \multirow[t]{2}{*}{$H L A-D w$} \\
\hline & $A$ & $\boldsymbol{B}$ & $C w$ & & \\
\hline RD & 1,11 & 27,8 & 2 & 6 & (3) 7 \\
\hline UB & 2,24 & 7,17 & - & 2,7 & 7 \\
\hline NP & $3, \mathrm{X}$ & w51,8 & - & 1,3 & 1,3 \\
\hline WC & 1,24 & w51,8 & - & 3 & 6,3 \\
\hline AW & 2,3 & $7, \mathrm{X}$ & $\mathrm{X}, \mathrm{X}$ & 3 & 2,4 \\
\hline BS & 2,31 & w14,w35 & 4 & 1,5 &,-- \\
\hline GA & $2, x$ & w39,w44 & 4 & 8 & $8,-$ \\
\hline JG & 1,3 & $8, w 35$ & 4 & 3 & 1,3 \\
\hline IC & $1, x$ & $8, X$ & - & 3 & 3 \\
\hline GB & $2, X$ & w37,40 & 3 & 3,7 & 4,6 \\
\hline JL & 2,11 & w35,12 & - & $5,7 \times 4$ & - \\
\hline VB & 1,3 & 8,40 & 3 & 3,6 & 3,6 \\
\hline JR & 3,24 & $8,14.2$ & - & 6 & 6 \\
\hline MP & 3,9 & 7,40 & 3 & - & - \\
\hline
\end{tabular}

\section{Discussion}

These results suggest the possibility of a disease susceptibility gene for cases of recurrent and chronic relapsing idiopathic inflammatory polyneuropathy associated with the HLA-A1, -B8, $-D R w 3$, and -Dw3 haplotype. These preliminary findings need to be confirmed in view of the relatively small number of cases examined and the borderline increased frequencies. On the other hand, they are supported by the findings of Stewart et al. (1978), who found a similar trend for an association with HLA-B8 and -DRw3 in 16 cases of chronic relapsing idiopathic polyneuritis. No significant associations were demonstrated for 22 cases of acute Landry-Guillain-Barré syndrome and six cases of subacute polyneuritis.

Stewart et al. (1978) also found an increase in HLA-Aw30 and -Aw31 which was not present in our series. Only one of the 14 was HLA-Aw30 or -Aw31. Since there is no linkage disequilibrium between HLA-Aw30/31 and -B8, -Dw3 and $-D R w 3$, the increased frequency raises the possibility of another disease susceptibility gene associated with these two HLA-A locus antigens. A more likely explanation is that the increased frequency is either a chance finding or spurious. Several sera that are used in the definition of these two antigens which are difficult to define may also give positive reactions in the presence of homozygous HLA-A2 cells (Wolf et al., 1975). Thus the apparent $A$ locus phenotype A2, Aw30/31 may in fact be HLA-A-2, -2 .

We wish to thank the Medical Research Council for financial support.

\section{References}

Adams, D., Gibson, J. D., Thomas, P. K., Batchelor, J. R., Hughes, R. A. C., Kennedy, L., Festenstein, H., and Sachs, J. (1977). HLA antigens in GuillainBarré syndrome. Lancet, 2, 504-505.

Table 2 Distribution (percentage values) of $H L A-D$ region antigens in chronic relapsing idiopathic inflammatory polyneuropathy

\begin{tabular}{|c|c|c|c|c|c|c|c|c|c|}
\hline & & \multicolumn{8}{|c|}{ Specificity } \\
\hline & & $w 1$ & $w 2$ & $w 3$ & $w 4$ & $w 5$ & w6 & $w 7$ & $w 8$ \\
\hline \multirow{2}{*}{ HLA-DW } & Patients (14) & 14 & 7 & 37 & 21 & - & 28 & 14 & 7 \\
\hline & $\begin{array}{l}\text { Control (99)* } \\
\text { Patients (14) }\end{array}$ & $\begin{array}{l}10 \\
21\end{array}$ & $\begin{array}{r}18 \\
7\end{array}$ & $\begin{array}{l}17 \\
50\end{array}$ & $\frac{21}{-}$ & $\begin{array}{l}15 \\
14\end{array}$ & $\begin{array}{l}\text { ND } \\
21\end{array}$ & $\begin{array}{l}17 \\
21\end{array}$ & $\begin{array}{c}\text { ND } \\
7\end{array}$ \\
\hline HLA-DR & Control $(351) \dagger$ & 14 & 21 & 17 & 23 & 30 & 17 & 27 & 15 \\
\hline
\end{tabular}

*European Caucasoids Histocompatibility Testing 1977, p. 362.

†Histocompatibility Testing 1977, p. 67. 
Arnason, B. G. W. (1975). Inflammatory polyradiculoneuropathies. In Peripheral Neuropathy, vol. 2, pp. 1110-1148. Edited by P. J. Dyck, P. K. Thomas, and E. H. Lambert. W. B. Saunders: Philadelphia.

Bodmer, J., Pickbourne, M., and Richards, S. (1978). Ia serology. In Histocompatibility Testing 1977, p. 35. Edited by W. F. Bodmer, J. R. Batchelor, J. G. Bodmer, F. Festenstein, and P. J. Morris. Munksgaard: Copenhagen.

Dyck, P. J., Lais, A. C., Ohta, M., Bastron, J. A., Okazaki, H., and Groover, R. V. (1975). Chronic inflammatory polyradiculoneuropathy. Mayo Clinic Proceedings, 50, 621-637.

Festenstein, H., Oliver, R. T. D., Sachs, J. A., McMichael, A., Bodmer, W., and Mendell, N. (1978). Overall analysis of the HTC data based on clusters, patterns and antigen reports. In Histocompatibility Testing 1977, p. 115. Edited by W. F. Bodmer, J. R. Batchelor, J. G. Bodmer, F. Festenstein, and P. J. Morris. Munksgaard: Copenhagen.

Latovitski, N., Sucio-Foca, N., and Penn, A. S. (1978). HLA studies in patients with the Guillain-Barré syndrome. Neurology (Minneapolis), 28, 338.
Pollard, J. D., King, R. H. M., and Thomas, P. K. (1975). Recurrent experimental allergic neuritis: an electron microscope study. Journal of the Neurological Sciences, 24, 365-383.

Stewart, G. J., Pollard, J. D., McLeod, J. G., and Wolnizer, C. M. (1978). HLA antigens in the Landry-Guillain-Barré syndrome and chronic relapsing polyneuritis. Annals of Neurology, 4, 285-289.

Thomas, P. K., Lascelles, R. G., Hallpike, J. F., and Hewer, R. L. (1969). Recurrent and chronic relapsing Guillain-Barré polyneuritis. Brain, 92, 589606.

Thorsby, E., and Piazza, A. (1975). Joint report from 6th Histocompatibility Workshop Conference II Typing for HLA-D. In Histocompatibility Testing 1975 , p. 414. Edited by F. Kissmeyer-Nielsen. Munksgaard: Copenhagen.

Wolf, E., Festenstein, H., Pritchard, J., Watson, B., Sachs, J., and Traub, N. (1975). Further HLA heterogeneity in Zambian and Caucasoid populations. In Histocompatibility Testing 1975, p. 179. Edited by F. Kissmeyer-Nielsen. Munksgaard: Copenhagen. 